Note

\section{A Short-step Synthesis of Theaspirane}

\author{
Hideki MaSuda and Satoru Mihara \\ Ogawa \& Co., Ltd., 6-32-9 Akabanenishi, \\ Kita-ku, Tokyo 115, Japan
}

Received August 22, 1984

Theaspirane has been found as a naturally occurring substance in raspberry, yellow passion fruit and tea. ${ }^{1)}$ The synthesis of theaspirane has been reported by some investigators. ${ }^{2)}$ We now report a new synthesis of theaspirane from $\beta$-ionone through dihydro- $\beta$-ionol.

When two equivalents of aluminium chloride hexahydrate $\left(\mathrm{AlCl}_{3} \cdot 6 \mathrm{H}_{2} \mathrm{O}\right)$ is present in sodium-ammonia reduction, $\beta$-ionone (1) can be efficiently reduced to dihydro$\beta$-ionol (2). The bromination of 2 using cupric bromide, followed by dehydrobromination in the presence of calcium carbonate, affords a mixture of $(E)$-theaspirane and $(Z)$-theaspirane. The process of synthesis is outlined in Scheme 1 .

\section{EXPERIMENTAL}

Commercially obtained $\beta$-ionone was used without further purification. IR, NMR and MS data were obtained on Hitachi 260-10, JEOL FX-100 and Hitachi M-80 spectrometers, respectively. The nuclear Overhauser effect (NOE) was measured on a Bruker AM-360 instrument.

Dihydro- $\beta$-ionol (2). To a solution of $\beta$-ionone $(1,5.0 \mathrm{~g}$, $26 \mathrm{mmol})$ and THF $(0.5 \mathrm{ml}), \mathrm{AlCl}_{3} \cdot 6 \mathrm{H}_{2} \mathrm{O}(14 \mathrm{~g}, 58 \mathrm{mmol})$ was added. Liquid ammonia $(30 \mathrm{ml})$ was then injected into the stirred solution. After the $\beta$-ionone had dissolved, $7.2 \mathrm{~g}$ $(0.31 \mathrm{~g} \cdot$ atom $)$ of sodium was added in small pieces, and the mixture was stirred under reflux conditions until the reaction was complete. After the addition of ammonium chloride $(2 \mathrm{~g}, 37 \mathrm{mmol})$, the mixture was stirred for an additional $5 \mathrm{~min}$ and then allowed to stand until the ammonia evaporated. The solvent was removed with a rotary evaporator, and the residue was diluted with water $(10 \mathrm{ml})$ and extracted with ethyl ether $(2 \times 30 \mathrm{ml})$. The organic layer was washed with brine, dried $\left(\mathrm{Na}_{2} \mathrm{SO}_{4}\right)$ and evaporated under reduced pressure. The residue was purified by column chromatography (silica gel $-\mathrm{AgNO}_{3}, n$ hexane-ethylacetate $=6: 1)$ to afford $3.9 \mathrm{~g}$ of $2(77 \%)$, which was identified to be dihydro- $\beta$-ionol. IR $v_{\max }^{\text {neat }} \mathrm{cm}^{-1}$ : $3320,2950,2900,1450,1370,1355,1125,1075$; identical with the published spectrum. ${ }^{3}{ }^{1} \mathrm{H} \mathrm{NMR} \delta_{\mathrm{TMS}}^{\mathrm{CDCl}_{3}}: 1.00(6 \mathrm{H}$, s, $\left.\mathrm{C}\left(\mathrm{CH}_{3}\right)_{2}\right), 1.20\left(3 \mathrm{H}, \mathrm{d}, J=7 \mathrm{~Hz}, \mathrm{CH}(\mathrm{OH}) \mathrm{CH}_{3}\right), 1.4 \sim 1.8$ $\left(6 \mathrm{H}, \mathrm{m}, \mathrm{CH}_{2}\right.$ at $\mathrm{C}\left(4,5\right.$ and $\left.\left.2^{\prime}\right)\right), 1.6\left(3 \mathrm{H}, \mathrm{m}, \mathrm{C}=\mathrm{C}-\mathrm{CH}_{3}\right)$, $1.8 \sim 2.3\left(4 \mathrm{H}, \mathrm{m}, \mathrm{C}=\mathrm{C}-\mathrm{CH}_{2}-\right.$ at $\mathrm{C}\left(3\right.$ and $\left.\left.1^{\prime}\right)\right), 2.77(1 \mathrm{H}$, br. s, OH), $3.80(1 \mathrm{H}, \mathrm{m}, \mathrm{CH}(\mathrm{OH}))$; identical with the published spectrum. $.^{4)} \mathrm{MS} m / z: 196\left(\mathrm{M}^{+}, 34 \%\right), 163(55)$, 136 (40), 123 (87), 121 (58), 109 (47), 107 (53), 95 (74), 93 (53), 82 (71), 81 (95), 69 (100), 55 (39), 43 (89); these values differ considerably from published data. ${ }^{4)}$

Theaspirane (3). To a stirred solution of the $2(4 \mathrm{~g}$, $20 \mathrm{mmol})$ in toluene $(40 \mathrm{ml})$ was added calcium carbonate $(8.9 \mathrm{~g}, 89 \mathrm{mmol})$ over a period of $10 \mathrm{~min}$. Cupric bromide $(15 \mathrm{~g}, 66 \mathrm{mmol})$ was then added, and the reaction mixture was stirred for $1 \mathrm{hr}$ at room temperature and heated to $40^{\circ} \mathrm{C}$ for $4 \mathrm{hr}$. The reaction mixture was then cooled, filtered and washed with ethyl ether. The filtrate was successively washed with water and saturated aqueous sodium bicarbonate solution and dried $\left(\mathrm{Na}_{2} \mathrm{SO}_{4}\right)$. After removal of the solvent, the residue $(4.2 \mathrm{~g})$ was purified by GPC $\left(\mathrm{CHCl}_{3}\right)$. The products were identified as $(E)$ theaspirane $((E)-3,46 \%)$ and $(Z)$-theaspirane $((Z)-3$, $26 \%$ ) by means of IR, NMR and MS. An assignment of the $(E)$ - and $(Z)$-configuration was mainly based on the

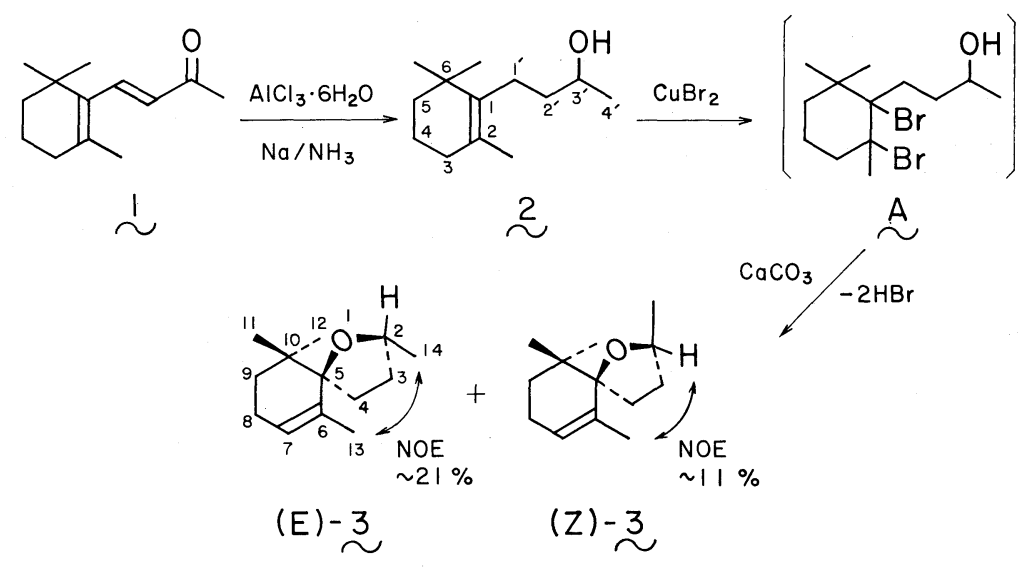

SCHEME 1. 
NOE of the $C(13)$ methyl group with irradiation at the $\mathrm{C}(2)$ methine proton or $\mathrm{C}(14)$ methyl group (see Scheme 1).

(E)-Theaspirane $((E)-3) . \quad \operatorname{IR} v_{\max }^{\text {neat }} \mathrm{cm}^{-1}: 2960,1670$, 1450, 1380, 1090, 1010, 830; MS $m / z: 194\left(\mathrm{M}^{+}, 0.3 \%\right), 179$ $\left(\mathrm{M}^{+}-\mathrm{CH}_{3}, 4\right), 139$ (42), 138 (100), 123 (34), 109 (45), 96 (63), 83 (47), 82 (76), 67 (32); and ${ }^{1} \mathrm{H}$ NMR $\delta_{\mathrm{TMS}}^{\mathrm{CDCl}_{3}: 0.87}$ and $0.94\left(6 \mathrm{H}, 2 \mathrm{~s}, \mathrm{C}\left(\mathrm{CH}_{3}\right)_{2}\right), 1.25(3 \mathrm{H}, \mathrm{d}, J=5.9 \mathrm{~Hz}$, $\left.\mathrm{C}(2)-\mathrm{CH}_{3}\right), 1.3 \sim 2.1\left(8 \mathrm{H}, \mathrm{m}, \mathrm{CH}_{2}\right.$ at $\mathrm{C}(3,4,8$ and 9$\left.)\right)$, $1.70\left(3 \mathrm{H}, \mathrm{m}, \mathrm{C}(6)-\mathrm{CH}_{3}\right), 4.11(1 \mathrm{H}, \mathrm{m}, \mathrm{C}(2)-\mathrm{H}), 5.24(1 \mathrm{H}$, $\mathrm{m}, \mathrm{C}(7)-\mathrm{H})$. These spectra of $(E)-3$ were in good agreement with reported values. ${ }^{2 \mathrm{c}, 5)}{ }^{13} \mathrm{C} \mathrm{NMR} \delta_{\mathrm{TMS}}^{\mathrm{CDCl}_{3}}$ : 18.5 , 20.9, 21.9, 22.9, 24.8, 34.3, 34.8, 35.3, 36.7, 76.8, 88.7, 121.4, 140.3. Found: $\mathrm{M}^{+} m / z$ 194.1676. Calcd. for $\mathrm{C}_{13} \mathrm{H}_{22} \mathrm{O}: m / z$ 194.1670.

(Z)-Theaspirane ((Z)-3). IR $v_{\max }^{\text {neat }} \mathrm{cm}^{-1}: \quad 2960, \quad 1670$, 1450, 1380, 1080, 1010, 830; MS m/z: $194\left(\mathbf{M}^{+}, 0.8 \%\right), 179$ $\left(\mathrm{M}^{+}-\mathrm{CH}_{3}, 8\right), 139$ (42), 138 (100), 123 (37), 109 (63), 83 (50), 82 (58), 67 (29); and ${ }^{\mathrm{i}} \mathrm{H}$ NMR $\delta_{\mathrm{TMS}}^{\mathrm{CDCl}_{3}}: 0.85$ and 0.97 $\left(6 \mathrm{H}, 2 \mathrm{~s}, \mathrm{C}\left(\mathrm{CH}_{3}\right)_{2}\right), 1.26\left(3 \mathrm{H}, \mathrm{d}, J=5.9 \mathrm{~Hz}, \mathrm{C}(2)-\mathrm{CH}_{3}\right)$, $1.5 \sim 2.1\left(8 \mathrm{H}, \mathrm{m}, \mathrm{CH}_{2}\right.$ at $\mathrm{C}(3,4,8$ and 9$\left.)\right), 1.70(3 \mathrm{H}, \mathrm{m}$, $\left.\mathrm{C}(6)-\mathrm{CH}_{3}\right), 4.01(1 \mathrm{H}, \mathrm{m}, \mathrm{C}(2)-\mathrm{H}), 5.40(1 \mathrm{H}, \mathrm{m}, \mathrm{C}(7)-\mathrm{H})$. These data were coincident with those of $(Z)-3$ in the literature. ${ }^{2 \mathrm{c}, 5) 13} \mathrm{C}$ NMR $\delta_{\mathrm{TMS}}^{\mathrm{CDCl}_{3}}$ : 19.3, 21.3, 23.0, 23.2, 24.0,
31.6, 33.8, 36.2, 38.0, 76.7, 87.8, 123.7, 137.2. Found: $\mathbf{M}^{+}$ $m / z$ 194.1664. Calcd. for $\mathrm{C}_{13} \mathrm{H}_{22} \mathrm{O}: m / z$ 194.1670.

Acknowledgment: We wish to express our gratitude to Mr. Y. Takai, Material Analysis Center in the Institute of Scientific and Industrial Research (Osaka University), for recording the NMR spectra.

\section{REFERENCES}

1) G. Ohloff, Fortschr. Chem. Org. Naturst., 35, 431 (1978).

2) a) S. Torii, K. Uneyama, T. Nakai and T. Yasuda, Tetrahedron Lett., 22, 2291 (1981); b) H. Okawara, S. Kobayashi and M. Ohno, Heterocycles, 13, 191 (1979); c) K. H. Schulte-Elte and F. Gautschi, W. Renold, A. Hauser, P. Fankhauser, J. Linacher and G. Ohloff, Helv. Chim. Acta, 61, 1125 (1978), and references cited therein.

3) M. Yamashita, K. Miyoshi, Y. Okada and R. Suemitsu, Bull. Chem. Soc. Jpn., 55, 1329 (1982).

4) C. Schmidt, K. L. Adams and U. Fechner, Can. J. Chem., 52, 1732 (1974).

5) W. Renold, W. Skorianetz, K. H. Schulte-Elte and G. Ohloff, Ger. Offen. 2504618 (1975). 